\title{
Tourism Destination Attractiveness as Perceived by Tourists Visiting Lake Nakuru National Park, Kenya
}

\author{
George Ariya ${ }^{1}$, Bob Wishitemi ${ }^{2}$, Noah Sitati $^{3}$ \\ ${ }^{1}$ Lecturer, University of Eldoret, Department of Tourism and Tour Operations Management, Eldoret-Kenya \\ ${ }^{2}$ Professor at School of Tourism, Hospitality and Events Management, Moi University, Eldoret-Kenya \\ ${ }^{3}$ Associate professor at School of Tourism, Hospitality and Events Management, Moi University, Eldoret-Kenya \\ \& CEO Maasai Mara Wildlife Conservation Association
}

*Corresponding Author: George Ariya, Lecturer, University of Eldoret, Department of Tourism and Tour Operations Management, Eldoret-Kenya

\begin{abstract}
Tourism destination attractiveness is the driving force for tourism in terms of visitors' perceived value yet wildlife protected areas' attractiveness like national parks has rarely been understood in tourism literature. The aim of this study was to establish tourism destination attractiveness as perceived by tourists visiting Lake Nakuru national park. Primary data was collected through self-administered structured questionnaires. Simple random sampling was used to select the sample size of 402 tourists. Data was analyzed through descriptive statistics while Principal Component Analysis was also done to verity the constructs underlying adopted scales. The results showed that safety and security inside the park and unique wildlife resources were very attractive $(M=2.14, S D=1.13)$ and $(M=2.24, S D=0.98)$ respectively. The findings indicated that safety and security inside the park $(M=2.14, S D=1.13)$ and unique wildlife resources $(M=2.24, S D=0.98)$ were the most valuable attributes to park visitors. The study adds new knowledge to tourism literature on park destination attractiveness as perceived by tourists and recommends that for park managers to sustain park attractiveness, security and uniqueness and imperative attributes in meeting tourists' needs and wants. Also variety of wildlife attractions and their close proximity to tourists are also important.
\end{abstract}

Keywords: Tourism destination attractiveness, tourists' perceptions, Lake Nakuru National Park.

\section{INTRODUCTION}

The concept of tourism destination attractiveness has received much attention in tourism literature (Buhalis, 2000; Ferrario, 1979; Formica, 2001, 2002; Formica \& Uysal, 2006; Gearing, Swart \& Var, 1974; Hu \& Ritchie, 1993; Kim, 1998; Kim \& Lee, 2002; Kozak \& Rimmington, 1998; Krešić \& Prebežac, 2011; Nyberg, 1994; Tam, 2012; Tasci, 2007; Vengesayi, 2003; Vengesayi, Mavondo \& Reisinger, 2009). The studies argue that destination attractiveness is the driving force of tourism and without which tourism would be almost nonexistent. Some also concur that the more a destination is able to meet the needs of tourists, the more the destination is likely to be chosen in preference to competing destinations (Kim \& Lee, 2002; Krešić \& Prebežac, 2011; Lee, Chen \& Huang, 2014; Vengesayi, 2003; Vengesayi et al., 2009).

Previous studies also observes that if tourists are attracted by special features embedded within a destination (Borst, Miedema, Vries, Grahama \& Dongena, 2008; Lee, Huang \& Yeh, 2010), their place attachment would be enhanced (Hou, Lin, \& Morais, 2005; Lee, 2001). For instance, Cheng, $\mathrm{Wu}$, and Huang (2012) acknowledge that place attachment is key indication of tourists' affective identification and dependence toward a destination. Tourism destinations, therefore, have an incredible power on establishing a person's destination of choice, expectations of satisfaction, intentions to revisit, perceptions of benefits and motivations, positive perception of opinion leaders, the amount of money spent and the duration of stay (Henkel, Henkel, Agrusa, Agrusa, \& Tanner, 2006).

While some literature reviewed in this study, such as Cracolici and Nijkamp (2009), Gunn (1979), Leask (2010), Kim and Agrusa (2005), Krešić (2007), Lew (1987), Mihalič (2000), Omerzel and 
Mihalič (2008), Pikkemaat (2004), Ritchie and Crouch (2005), Um, Chon and Ro (2006), Vengesayi (2003), Yoon and Uysal (2005) among others recognize the importance of tourism attractions as key determinants of destination attractiveness, some attributes may be attractive to tourists and are universally important, while others may not be and are only important for specific types of destinations (Lin, Morias, Kerstetter \& Hou, 2007). Limited documented studies have also investigated specific destination attractiveness attributes applicable to wildlife tourism within protected areas (PAs). This assertion includes Kenya's wildlife tourism product despite Kenya's tourism industry being predominantly wildlife-based and backbone of tourism industry (Chongwa, 2012; GoK, 2013; Elliot, Gibbons, King \& King, 2014; Munyiri, 2015).

A recent study in Kenya for instance estimates that the country's PAs account for an estimated 90 percent of wildlife tourism and about 75 percent of total tourist earnings (Chongwa, 2012). Another study acknowledges that one out of two international visitors to Kenya is anticipated to have at least one wildlife appreciative/viewing opportunity during their stay (Odunga \& Maingi, 2011). This concurs with GoK (2010) view that national parks and reserves have developed into major centers of wildlife tourism activities for wildlife viewing and photography of its unique savanna grasslands and the game. One of the Kenya's premier wildlife destinations is Lake Nakuru National park (LNNP) in Nakuru County, Kenya. The park has significant ecological and fragile ecosystem that contributes to national economy through tourism in Kenya (Dharani, Kinyamario \& Onyari, 2006). Despite the park's premium ranking, little attention has been devoted to investigate the perceived attributes' attractiveness yet Lee et al. (2014) assert that wildlife attractions' uniqueness, abundance, accessibility and visibility are key determinants of destination attractiveness. Therefore, the study intended to empirically establish the attractiveness of destination attributes at LNNP as perceived by visitors.

\section{LITERATURE REVIEW}

\subsection{Concept of Tourism Destination Attractiveness}

The word attractiveness itself originates from the Latin verb "atrathere", meaning-to attract (Gunn, 1987). So it can be argued that if some characteristic of tourism destination is to be considered tourism attraction it necessarily must have features that are interesting and attractive to potential tourists. Attractiveness is often defined with reference to the features or attributes of a specific destination. For instance, while some studies assess destination attractiveness by exploring the inventory of existing tourism destination resources and attractions (Backman, Uysal \& Backman, 1991; Ferrario, 1979), others investigate the perceptions that tourists have of destination resources and attractions (Hu \& Ritchie, 1993; Kim, 1998; Ritchie \& Zins, 1978). Further, the integration of the two issues into a single empirical study is also found in previous research, in which respondents were those who were widely experienced in dealing with tourists, rather than the tourists themselves (Formica \& Uysal, 2006; Gearing et al., 1974).

This delineation of destination attributes concept represents what is referred to as the 'supply-driven' approach to attractiveness. That is, attractiveness is a force that draws tourists, as a result of the 'overall attractions existing in a given place at a certain time' (Formica \& Uysal, 2006: 419). Under this approach, a destination is a 'supplier of spatial tourist services with distinct attractiveness features' (Cracolici \& Nijkamp, 2009: 337; see also Tardivo \& Viassone, 2009). Another approach to attractiveness focuses instead on the tourist versus the destination, and can be said to be 'demand driven' (Formica \& Uysal, 2006). Under this approach, attractiveness is a function of the tourist's perception of the ability of the destination to satisfy their needs and deliver personal benefits (Mayo \& Jarvis, 1980). This multifaceted nature of a destination presents the considerable challenge of matching tourism resources and attractions with tourist motivations and preferences (Piperoglou, as cited in Formica and Uysal, 2006).

Tourism destination attractiveness has been extensively defined by scholars. Mayo and Jarvis (1981:22) for instance conceptualized the notion of destination attractiveness by relating it to the traveler's decision-making process and the specific benefits derived by travelers. They define the notion of destination attractiveness as 'a combination of the relative importance of individual benefits and the perceived ability of the destination to deliver individual benefit'. This ability is enhanced by specific attributes of a destination that makeup the destination such as attractions, infrastructure or services and people providing these services. Further, Van Raaij (1986) viewed a tourism destination 
as a set of attributes that are partly "given" and partly "man-made". In the "given" part, there are a number of natural features of a tourism destination, such as the climate, scenery, beaches, mountains, historic-cultural buildings, and so forth. In the "man-made" part, there exist features such as hotel and transportation facilities, package tours and facilities for sports and recreation, which can be adapted to customer preferences, subject to budget restrictions.

$\mathrm{Hu}$ and Ritchie (1993:25) regards the attractiveness of a travel destination as 'the feelings, beliefs, and opinions that an individual has about a destination's perceived ability to provide satisfaction in relation to his or her special vacation needs.' They assert that a tourism destination is therefore a combination of destination attributes mostly tourist facilities and services. This observation concurs with Leiper $(1990 ; 1991)$ and Vengesayi et al. (2009) view that destination attractiveness are opinions of visitors about the destination's perceived ability to satisfy their needs or goals. With regard to the importance of the destination attributes, the term is defined as the sum of belief, ideas and impressions of characteristics or attributes that a tourist has of a place (Kotler, Haider \& Rein, 1993). Lue, Crompton and Stewart (1996:43) further acknowledge attractiveness as 'something recognized by individuals as a factor that influences their decision-making of pleasure travel' while Kim (1998) perceives tourism destination attractiveness as a package of tourism facilities and services.

In terms of spatial dimension, destination attractiveness is considered as places or geographical regions that offer an amalgam of tourism products and services (Buhalis 2000; UNWTO, 2003) with physical and administrative boundaries that define its management, images/perceptions of market competitiveness (UNWTO, 2003). Buhalis (2000) further elaborates that they comprise the entire range of facilities and services offered locally, together with all socio-cultural, environmental resources and public goods. Vengesayi (2003: 638) refers to attractiveness as reflecting the 'feelings and opinions of visitors about the destination's perceived ability to satisfy their needs'. Cracolici and Nijkamp (2009: 337) similarly speak about 'the extent to which the availability, quality and management of local tourist services satisfies the needs of the customer'.

Marachat (2003) operationalizes destination attractiveness concept as tourist's feelings, beliefs, attitudes, opinions, or perceptions of specific destination attributes or factors that influence a tourist's decision of which specific destination should be selected. He further observes that the overall or global attractiveness is the function of the affective evaluations of the destination and the perceptions of attribute. Krešic (2007: 1813) refers to attractiveness as comprising 'those attributes of a tourism destination which, with their specific features, attract or motivate tourists to visit'. Cho (2008: 221) similarly states that attractiveness 'is an aggregated indicator of attributes that make a specific location appealing as a potential destination to travelers'. The list of attributes that might enhance destination attractiveness for tourists is potentially large. Krešić \& Prebežac, (2011) simply reports that they are specific destination features with the ability to attract visitors while Lee, Ou and Huang (2009) provides a summary that attractiveness of a destination is determined by its unique overall attributes.

In the per view of this study as rooted in the aforementioned literature review, tourism destination attractiveness will be conceptualized as perceived value of wildlife destination attributes in regard to meeting tourists needs and goals. This is further derived from the assertion that the deficiency in the literature is still the need to identify what sector-specific attributes predispose people towards a certain tourist activity and further lead them to choose one destination over another (Formica, 2002; Tam, 2012).

\subsection{Attributes of Tourism Destination Attractiveness}

Different researchers have offered different perspectives of what constitutes tourism destination attributes. Van Raaij (1986) viewed the "given" part destination attributes as natural features such as the climate, scenery, beaches, mountains, historic-cultural buildings, and so forth while the "manmade" attributes as hotel and transportation facilities, package tours and facilities for sports and recreation, which can be adapted to customer preferences, subject to budget restrictions. On the other hand, Laws (1995) grouped destination attributes into two major categories: primary and secondary. The primary category includes innate characteristics such as climate, ecology, natural resources, culture, and historical architecture. The secondary characteristics are those developments introduced particularly for tourists such as hotels, catering, transport, activities, and entertainment. Buhalis 
(2000) mentions attractions, accessibility, available packages activities and ancillary services as core destination provisions. Goeldner, Ritchie and McIntosh (2000) also categorized attractions attributes into five main groups: cultural, natural, events, recreation, and entertainment.

Gearing et al. (1974) grouped these attributes into the following five major categories: natural factors, special factors, historical factors, recreational and shopping facilities, and infrastructure, food, and shelter. Hu and Ritchie (1993) also identified sixteen touristic attributes derived from (with some departures and extensions) previous destination attractiveness studies conducted by Gearing et al. (1974) and Ritchie and Zins (1978) as climate, availability/quality of accommodations, sports/recreational opportunities, scenery, food, entertainment, uniqueness of local people's life, historical attractions, museums/cultural attractions, communication difficulty due to language barriers, festivals/special events, accessibility, shopping, attitude towards tourists, availability/quality of local transportation, and price levels.

In their study on destination attractiveness based on supply and demand indicators, Formica and Uysal (2006) acknowledge that the overall tourism attractiveness of a destination depends on the relationship between the availability of existing attractions and the perceived importance of such attractions. They identified tourist attraction supply variables as tourism services and facilities, eating and drinking places, retail sales, souvenir firms, travel agencies, hotel and motel rooms, golf courses, cultural/historical, historic buildings, museums, historical districts, civil war sites, festivals, wineries, rural lodging, campsites, cottages/cabins, bed and breakfast, recreational vehicle parks, outdoor recreation, horseback riding, falls, hiking, and biking. As tourists patronize local businesses, they are exposed to or experience the background tourism elements, such as natural, socio-cultural, and manmade attractions that frequently constitute tourists' main reasons for travel. These elements collectively produce the ultimate tourism experience and can be examined simultaneously in the same context (Pyo, Uysal, \& McLellan, 1991).

Krešić and Prebežac (2011) provided nineteen destination attributes as image of the country; feeling of personal safety; quality of the country's promotion; climate; scenic beauty; accessibility; quality of information in destination; urban and architectural harmony of the place; environmental preservation; tidiness of the place; friendliness, quality of accommodation; quality of restaurants; presentation of cultural heritage; entertainment opportunities; sport and recreation opportunities; shopping opportunities; and 'value for money' while Tam (2012) categorized seventeen destination attributes as safety and security; scenery; price levels; cultural attractions; attitude towards tourists; uniqueness of local people's life; food; availability/quality of local transportation; historical attractions; entertainment activities; festivals special events; communication difficulties; availability/quality of accommodations; weather and climate; shopping; accessibility; and sports/recreational opportunities

The importance of these attributes helps people to evaluate the attractiveness of a destination and make destination choices. The more a destination is able to meet the needs of its visitors, the more it is perceived to be attractive and the greater the probability that it will be selected as the final destination (Kim \& Lee, 2002). The influence of destination attractiveness is not limited to the stage of selecting the destination, but also affects the behavior of tourists in general. It is noted that destination attractiveness is the most significant predictor of revisit intention (Kozak \& Rimmington, 1998; Sparks, 2007; Um, Chon \& Ro, 2006). In other words, the more impressed visitors are with the destination, the greater visitation frequency is expected. An investigation of the impact of destination attributes on frequency of visitors and their intention to return could demonstrate the strengths and weaknesses of a destination by assessing its attractiveness level (Lee et al., 2009). Other authors have pointed to such features as the price of venues, transportation, climate, and quality of accommodation (Cho, 2008; Gartner, 1989), as well as destination image (Anholt 2010; Babić-Hodović, Mehic, Kramo \& Resic, 2008; Harrison-Walker, 2011; Kim \& Perdue, 2011). Indeed, Vengesayi (2008) states that virtually every destination attribute has been identified at some stage as a source of its attractiveness to tourists.Although literature has documented many destination attributes that determine the attractiveness of a tourism destination, the magnitude and strength of each attribute are not being explored. Only few attempts are also made to categorize the attributes that are important to destinations and investigate their magnitude, strength, and contribution to destination attractiveness (Vengesayi et al., 2009). So far, there has not been sufficient investigation carried out to determine the underlying dimensions of destination attractiveness and the strength of each attribute in relation to a single wildlife tourism destination hence the justification of this study. 


\section{STUdy AREA AND METHOdology}

This study was done in September 2016 to May 2017 at Lake Nakuru National Park within Rift valley in Kenya. In 1987, the park was established as Kenya's first rhinoceros sanctuary (Dharani et al., 2006), being a home to globally-threatened White rhino (Ceratotherium simum) and Black rhino (Diceros bicornis). On 5th June 1990, the park was designated Kenya's first Ramsar Site or a Wetland of International Importance. It has also been designated as an Important Bird Area (IBAs are sites of international significance for the conservation of birds) by Bird Life International. The park is also known due to millions of Greater and Lesser flamingos and other bird species representing one of the greatest ornithological spectacles on earth (GoK, 2010).

The study adopted cross-sectional survey design. The target population composed of tourists visiting Lake Nakuru national park. A total of four hundred and two (402) respondents completed the questionnaires for the study. In order to select tourists as participants, simple random sampling technique was used to select participants visiting the park for self-administered questionnaires. All tourists visiting the park at the time of the study and were willing to fill in questionnaires were simple randomly sampled for the questionnaire dissemination. Data was analyzed through descriptive and inferential statistics and presented inform of graphs and tables.

\section{RESULTS AND DISCUSSION}

A total of 402 respondents were interviewed through questionnaires during the study period. In terms of gender, majority of the respondents were male (56.2\%) while female were $43.8 \%$. According to the study findings, most visitors to LNNP were youthful (Figure 1).

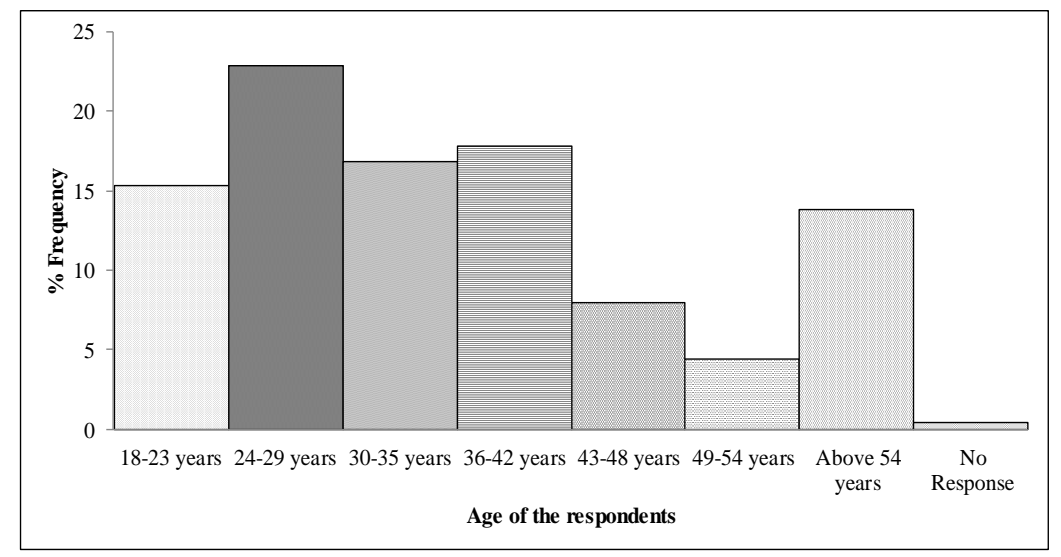

Figure4. Histogram showing age distribution of the tourists' respondents

In terms of level of education, majority of the respondents had post-secondary education while occupation-wise, majority of the respondents were employed (Table 1). Most of the respondents had yearly income level of less than US\$20,000 while in terms of nationality, majority of the respondents were non-residents (Table 1).

Table1. Table showing profile of the tourists' respondents at LNNP

\begin{tabular}{|l|l|c|c|}
\hline Profile & & Frequency & Percentage (\%) \\
\hline Gender & Male & 226 & 56.2 \\
\hline & Female & 176 & 43.8 \\
\hline & Total & $\mathbf{4 0 2}$ & $\mathbf{1 0 0}$ \\
\hline Age & $18-23$ years & 62 & 15.4 \\
\hline & $24-29$ years & 92 & 22.9 \\
\hline & $30-35$ years & 68 & 16.9 \\
\hline & $36-42$ years & 72 & 17.9 \\
\hline & $43-48$ years & 32 & 8.0 \\
\hline & $49-54$ years & 18 & 4.5 \\
\hline & Above 54 years & 56 & 13.9 \\
\hline & No Response & 2 & 0.5 \\
\hline & Total & $\mathbf{4 0 2}$ & $\mathbf{1 0 0}$ \\
\hline Education & Less than high school & 18 & 4.5 \\
\hline & High school & 56 & 13.9 \\
\hline
\end{tabular}




\begin{tabular}{|l|l|c|c|}
\hline & College & 116 & 28.9 \\
\hline & University degree & 104 & 25.9 \\
\hline & University higher degree & 108 & 26.8 \\
\hline & Total & $\mathbf{4 0 2}$ & 36.3 \\
\hline Yearly income & Less than US\$ 20,000 & 146 & 22.4 \\
\hline & US\$ 20,001-40,000 & 90 & 10.0 \\
\hline & US\$ 40,001-60,000 & 40 & 6.5 \\
\hline & US\$ 60,001-80,000 & 26 & 11.4 \\
\hline & US\$ 80,001 and above & 46 & 13.4 \\
\hline & No response & 54 & $\mathbf{1 0 0}$ \\
\hline & Total & $\mathbf{4 0 2}$ & 43.3 \\
\hline Nationality & Kenya & 174 & 8.5 \\
\hline & Africa & 34 & 18.9 \\
\hline & Europe & 76 & 17.4 \\
\hline & America & 70 & 3.5 \\
\hline & Asia & 14 & 7 \\
\hline & Australia \& New Zealand & 28 & 1.4 \\
\hline & No response & 6 & $\mathbf{4 0 2}$ \\
\hline & Total & $\mathbf{1 0 0}$ \\
\hline
\end{tabular}

\subsection{Factor Analysis on the Attractiveness of Lake Nakuru National Park (LNNP)}

Factor analysis (FA) was performed on the initial twelve items of destination attributes to determine the underlying dimensions of the attractiveness of the wildlife tourism sector and establish attribute constructs that explain most of the variances between the attributes (Hair et al., 2002). The preconceived factors that were used to measure perceived attribute importance were selected from previous studies of destination attractiveness with some modifications to fit national park as a destination under this study.

Factor Analysis using Principal Component Analysis (PCA) with Orthogonal Varimax Rotation was used to identify the underlying destination attributes that explained the variance in the attribute. The correlation matrix revealed a substantial number of variables correlated at 0.30 level or above. The Kaiser-Meyer-Olkin value for measuring sample adequacy was 0.799 exceeding the recommended value of 0.6 (Kaiser, 1970, 1974). The Barlett Test of Sphericity (Bartlett, 1954) was statistically significant $(\mathrm{p}<0.001)$, supporting the factorability of the correlation matrix. Therefore, the data was considered suitable for the proposed statistical procedure of factor analysis (Hair, Black, Babin, Anderson \& Tatham 2006).

The principles components analysis revealed the presence of four components with eigenvalues exceeding 1, explaining $36.1 \%, 49.1 \%, 60.8 \%$, and $69.8 \%$ of the variance respectively, which were retained for further analysis. An inspection of the screeplot revealed a clear break after the fourth component. Using Catell's (1966) scree test, it was decided to retain four components for further investigation. This was further supported by the results of parallel analysis, which showed four components with eigenvalues exceeding the corresponding criterion values for a randomly generated data matrix as shown in Table 2 .

Table2. Table showing the comparison of eigenvalues from principles components analysis (PCA) and the corresponding criterion values obtained from parallel analysis

\begin{tabular}{|c|c|c|c|}
\hline Component number & Actual eigen values from PCA & Criterion value from parallel analysis & Decision \\
\hline 1 & 4.327 & 1.1308 & Accept \\
\hline 2 & 1.568 & 1.0525 & Accept \\
\hline 3 & 1.403 & 0.9969 & Accept \\
\hline 4 & 1.084 & 0.9437 & Accept \\
\hline 5 & 0.638 & 0.5761 & Reject \\
\hline
\end{tabular}

The rotated solution revealed the presence a number of strong loadings above 0.5 (Table 3). The attractiveness attributes 'guiding fee', 'park entry fee', and 'cost of meals and/or accommodation' loaded on Component 1 contributing 17.73\% variance. Attributes that loaded on Component 2 were; 'abundance of wildlife resources', 'unique wildlife resources', and 'variety of wildlife resources' contributing 17.48\%. Component 3 loaded attributes included 'park branding as rhino sanctuary', 
'park branding as bird sanctuary', and 'safety and security inside the park' contributing $17.39 \%$ while Component 4 loaded attributes included 'quality of road systems', 'quality of park route signs', and 'proximity of attraction sites' contributing $17.25 \%$ as summarized in Table 3. Cumulatively, the four component solution explained a total of $69.8 \%$ of the total variance. The four conceptually meaningful factors were labeled as: factor 1, pricing of attractions; factor 2, wildlife resources; factor 3 , park image; and factor 4, park accessibility as shown in Table 3

Table3. Table showing the result of factor analysis on wildlife destination attributes attractiveness

\begin{tabular}{|c|c|c|c|c|c|c|c|}
\hline \multirow{2}{*}{ Attributes } & \multicolumn{4}{|c|}{ Factor loading } & \multirow{2}{*}{ Eigenvalue } & \multirow{2}{*}{\begin{tabular}{|l} 
Explained $(\%)$ \\
Variance
\end{tabular}} & \multirow{2}{*}{ Communality } \\
\hline & Factor 1 & Factor 2 & Factor 3 & Factor 4 & & & \\
\hline $\begin{array}{l}\text { Factor 1: Pricing of } \\
\text { attractions }\end{array}$ & & & & & 4.327 & 17.73 & \\
\hline Guiding fee & 0.818 & & & & & & 0.730 \\
\hline Park entry fee & 0.803 & & & & & & 0.688 \\
\hline $\begin{array}{l}\text { Cost of meals and/or } \\
\text { accommodation }\end{array}$ & 0.790 & & & & & & 0.653 \\
\hline $\begin{array}{l}\text { Factor 2: Wildlife } \\
\text { resources }\end{array}$ & & & & & 1.568 & 17.48 & \\
\hline $\begin{array}{l}\text { Abundance of wildlife } \\
\text { resources }\end{array}$ & & 0.818 & & & & & 0.698 \\
\hline $\begin{array}{l}\text { Unique wildlife } \\
\text { resources }\end{array}$ & & 0.815 & & & & & 0.693 \\
\hline $\begin{array}{l}\text { Variety of wildlife } \\
\text { resources }\end{array}$ & & 0.702 & & & & & 0.666 \\
\hline Factor 3: Park Image & & & & & 1.403 & 17.39 & \\
\hline $\begin{array}{l}\text { Park branding as rhino } \\
\text { sanctuary }\end{array}$ & & & 0.854 & & & & 0.812 \\
\hline $\begin{array}{l}\text { Park branding as bird } \\
\text { sanctuary }\end{array}$ & & & 0.776 & & & & 0.709 \\
\hline $\begin{array}{l}\text { Safety and security } \\
\text { inside the park }\end{array}$ & & & 0.721 & & & & 0.694 \\
\hline $\begin{array}{l}\text { Factor 4: Park } \\
\text { Accessibility } \\
\end{array}$ & & & & & 1.084 & 17.25 & \\
\hline $\begin{array}{l}\text { Quality of road } \\
\text { systems }\end{array}$ & & & & 0.836 & & & 0.742 \\
\hline $\begin{array}{l}\text { Quality of park route } \\
\text { signs }\end{array}$ & & & & 0.816 & & & 0.708 \\
\hline $\begin{array}{l}\text { Proximity to attraction } \\
\text { sites }\end{array}$ & & & & 0.643 & & & 0.589 \\
\hline \begin{tabular}{|l|} 
Total variance \\
explained
\end{tabular} & & & & & & 69.85 & \\
\hline \multicolumn{8}{|c|}{ Note: Attractiveness- $1=$ Outstandingly attractive and $5=$ Not attractive } \\
\hline \multicolumn{8}{|c|}{ Extraction Method: Principal Component Analysis. } \\
\hline \multicolumn{8}{|c|}{ Rotation Method: Varimax with Kaiser Normalization. } \\
\hline \multicolumn{8}{|c|}{ KMO (Kaiser-Mayer-Olkin measure of sampling adequacy) $=0.799$} \\
\hline Bartlett's test of spheric & city: $\mathrm{p}<0.0$ & & & & & & \\
\hline
\end{tabular}

The results of this analysis also support the use of positive affect items and the negative affect items as separated scales, as suggested scale authors (Watson et al., 1988). Thus, the data suggest that the scale and the attributes developed for measuring the attractiveness of Lake Nakuru national park were reliable and valid instrument to measure the attractiveness of a wildlife-based tourism destination.

Parks play an imperative role as an avenue and a nature resource site for leisure and recreational needs of the people (Yahaya \& Mohd, 2013). The activities and outcomes from the experience of both onsite and off-site of the destinations could bring satisfaction to visitors (Abdullah, Amat-Ramsa \& Mohd-Ariff, 1999). There are several factors associated to park visitation including socioeconomic background, recreational opportunities and attributes of the park that attract people (Cohen \& Golinelli, 2009; McCormack \& Rock 2010). Studies on park visitation have also shown that the contributed attributes are influenced mainly by the parks' attractions (Cohen \& Marsh, 2010; Yahaya $\&$ Mohd, 2013). Factor analysis resulted in the four dimensions of destination attractions namely 
pricing of attractions, wildlife resources, park image, and park accessibility (Table 3). They were found to determine the character of a wildlife tourism destination and provide value or importance to see or experience wildlife tourism destination.

\subsection{Respondents' Perceived Attractiveness of Lake Nakuru National Park}

An evaluation on twelve attributes performance in terms of attractiveness of the park was conducted by indexing the attractiveness attributes through the overall mean. Using the five-point attractiveness scale options of Outstandingly Attractive, Very Attractive, Attractive, Fairly Attractive, and Not Attractive; the anchor points of the scale had numerical values of

$1,2,3,4$, and 5 respectively. For decisions to be made, the mean of the scaling point was computed as:

$$
1+2+3+4+5=3.00
$$

Therefore, in the interpretation, responses with means between 2.00 to 2.40 was regarded as very attractive, 2.5 to 2.90 attractive while mean of 3.00 and above was regarded as not attractive. The simple average technique was then used to obtain an average score for each attractiveness factor as rated by respondents as shown in Table 4 .

Table4. Table showing the respondents' perceived attractiveness of LNNP

\begin{tabular}{|c|l|c|c|l|}
\hline Ranking & \multicolumn{1}{|c|}{ Attractiveness attributes } & $\begin{array}{c}\text { Mean } \\
\text { score* }\end{array}$ & Std. Deviation & \multicolumn{1}{|c|}{ Remarks } \\
\hline 1 & Safety and security inside the park & 2.14 & 1.13 & Very Attractive \\
\hline 2 & Unique wildlife resources & 2.24 & 0.98 & Very Attractive \\
\hline 3 & Variety of wildlife resources & 2.53 & 1.08 & Attractive \\
\hline 4 & Proximity to attraction sites & 2.56 & 1.17 & Attractive \\
\hline 5 & Quality of park route signs & 2.56 & 1.3 & Attractive \\
\hline 6 & Quality of road systems & 2.62 & 1.27 & Attractive \\
\hline 7 & Abundance of wildlife resources & 2.64 & 1.24 & Attractive \\
\hline 8 & Park branding as rhino sanctuary & 2.65 & 1.39 & Attractive \\
\hline 9 & Park branding as bird sanctuary & 2.68 & 1.3 & Attractive \\
\hline 10 & Park entry fee & 3.25 & 1.31 & Not Attractive \\
\hline 11 & Guiding fee & 3.41 & 1.52 & Not Attractive \\
\hline 12 & Cost of meals and/or accommodation & 3.90 & 1.68 & Not Attractive \\
\hline
\end{tabular}

*The scores we obtained by utilizing the simple average technique, Scale: $1=$ Outstandingly Attractive, $2=$ Very Attractive, 3=Attractive, 4=Fairly Attractive, 5= Not Attractive

When the twelve attributes of Lake Nakuru National park as a destination were rated in terms of their attractiveness by the respondents, safety and security inside the park and unique wildlife resources were rated as very attractive in first and second rating respectively (Table 4). Variety and proximity of wildlife resources, quality of park route signs, quality of road systems, abundance of wildlife resources, park branding as rhino sanctuary and park branding as bird sanctuary were rated as attractive. Park entry fee, guiding fee and cost of meals and/or accommodation were rated as not attractive. The results concur with study by Thiumsak and Ruangkanjanases (2016) on factors influencing international visitors to revisit Bangkok, Thailand where concerning the perceived attractiveness, the destination attributes which earn the highest average score was safety. Another study regarding perceived attractiveness on destination by Zhou (2005) on the destination attributes attracting international tourists to Cape Town included established that price, landscape, safety, service (shopping, accommodation, food, and transportation), entertainment, and culture \& history have a significantly positive correlation with the decision on destination choice.

Global insecurity has affected tourism industry including Kenya. In Kenya for example, ethnic violence, political unrest and terrorism incidences have affected tourism industry (Mayaka \& Prasad, 2012). Key examples include the 2013 attack on the West Gate Mall; the 2007-2008 post-election violence and the 1998 bombing, bombing of paradise hotel in Kikambala (Mburugu \& Rotich, 2015; WTTC, 2012). These incidences triggered fears among international tourists thus affecting Kenya as a destination (Mburugu \& Rotich, 2015). There is also a display pattern of terrorism repeat attacks in 
Kenya. Therefore, these current terrorism incidences and the perceived threat image they project nationally and internationally could have contributed to safety and security at Lake Nakuru national park being the highest priory to visitors.

The respondents also rated unique wildlife resources as very attractive (Table 4). Study by Ritche and Zins, 1978, but in different destination set up, has also established that natural uniqueness is a potential 'pull' factor for tourists. In a different study, Hu and Ritchie (1993) reported that the most important touristic attributes was the uniqueness of the way of life of the local population and historical attractions. Study by Murphy, Pritchard and Smith (2000) also assert that features such as the natural environment and other primary features (such availability of attractions and amenities, etc.) may be primary determinants in defining the value of a destination for tourists.

Other researchers have also established that tourists have wide interest in wildlife based tourism activities attaching value on uniqueness, abundance and variety (Curtin \& Wilkes, 2005; Newsome et al., 2005). Lake Nakuru national park is internationally known as a home to globally-threatened White (Ceratotherium simum) and Black (Diceros bicornis) rhinos as well as bird sanctuary (Dharani et al., 2006; GoK, 2010). The park is also considered as wetland of international importance. This could have made the park's wildlife resources more unique in meeting tourists' needs and goals. In terms of variety, the park offers the best opportunity especially for ornithological safaris since the park is also known due to millions of Greater and Lesser flamingoes and other bird species representing one of the greatest ornithological spectacles on earth (GoK, 2010).

\section{CONCLUSION AND RECOMMENDATION}

The purpose of this study was to investigate tourism destination attractiveness as perceived by tourists visiting Lake Nakuru national park. The study therefore concludes that development of wildlife destination attributes through principal components factor analysis with orthogonal varimax rotation provided the scales and attributes that can be used to measure protected area destination attractiveness; an area with limited literature in tourism discipline. Moreover, regarding perceived attractiveness of wildlife resources at Lake Nakuru national park, uniqueness of wildlife resources was perceived to be most attractive to visitors in meeting their destination needs and goals. This was followed by variety of wildlife resources. Studies have also established that natural uniqueness of a destination is a potential key 'pull' factor for tourists. Thus, unique wildlife resources, variety of wildlife resources are primary determinants in defining the value of a destination for tourists.

Moreover, accessibility of protected areas in terms of access to attraction sites, well designed park route signs and quality of road system are also crucial on determining destination attractiveness. The results showed that proximity of attraction sites was more valuable to tourists, followed quality of park route signs and quality of road systems respectively. Recent tourism literature indicates that there is increase in demand and opportunities to view wildlife (especially unusual or endangered) in their natural or captive setting at close range in fulfilling their enjoyment of the experience, especially among international tourists. Moreover, a well-developed transport network within the park with quality park route signs is of great value in achieving destination attractiveness.

While destination cost can also influence destination choice, tourists perceive positive value when the benefits received while traveling are greater than the costs invested in travel. The study established that park entry fee, guiding fee, and cost of meals and/or accommodation was rated by tourists as not attractive. Research has established that price at which tourism product is offered creates expectations of its quality and is related to product value. Therefore, tourists may not attach too much value on a premium price if their expectation of quality and product value is met.

Destination image can also significantly impact on tourists' choice and key construct in destination selection. Safety and security inside the park was rated by tourists as outstandingly attractive. Tourists also rated park branding as bird and rhino sanctuary as attractive. Therefore, park reputation is a major variable that influences choice for park visitation. Lake Nakuru national park is an international re-known brand as an important bird area, rhino sanctuary and wetland of international importance. Therefore, tourists exert a lot of value on the already created images nationally and internationally. Important to also note is that safety and security inside the parks was rated the highest. Therefore, safety and security within protected areas is considered most valuable factor for visitors to Lake Nakuru national park. The study further recommends that: 
1. In a premium destination like Lake Nakuru national park, wildlife resources attributes in terms of their uniqueness, variety and abundance are valuable indicators of park destination choice. How park managers sustain park uniqueness, variety and abundance of attractions in the midst of serious ecological challenges currently facing the park could influence destination choice by tourists in the future.

2. To improve accessibility of Lake Nakuru national park, the park officials should invest more on infrastructure, despite the current damage by increasing lake water levels. Quality of road systems and appropriate signage within the park could be of great value to tourists.

3. Expanding demand for closer interactions with wildlife in their natural habitats also means proximity and accessibility of wildlife attractions must be a consideration by destination managers in satisfying this demand.

4. Lake Nakuru national park has been priced as a premium park, while the park entry fee might not be of great concern for tourists currently, the sustainability of park pricing in future will be complex based on the current ecological changes that continue to occur inside the park. These changes could also adversely affect park's image internationally if mitigation measures are not established.

\section{REFERENCES}

[1] Abdullah, M., Amat Ramsa, Y., \& Mohd Ariff, J. (1999). Recreational Opportunities for Public Use in Ayer Hitam Forest: Setting the Stage and Park Management Approach. Pertanika Journal of Tropical Agriculture Science, 22(2), 161-166.

[2] Anholt, S. (2010). Places: Identity, image and reputation. Basingstoke: Palgrave Macmillan.

[3] Babić -Hodović V., Mehic, E., Kramo, A., \& Resic, E. (2008). Tourist destination image and perception: The case of Bosnia and Herzegovina, An enterprise Odyssey. Paper presented at the International Conference Proceedings, $11^{\text {th }}-14^{\text {th }}$ June 2008, Zagreb.

[4] Backman, S., Uysal, M., \&. Backman, K. (1991). Regional Analysis of Tourism Resources. Annals of Tourism Research, 8(1), 323-7.

[5] Bartlett, M. S. (1954). A note on the multiplying factors for various chi square approximations. Journal of the Royal Statistical Society, 16 (Series B), 296-298.

[6] Borst, H. C., Miedema, H. M. E., Vries, S. I., Grahama, J. M. A., \& Dongena, J. E. F. (2008). Relationships between street characteristics and perceived attractiveness for walking reported by elderly people. Journal of Environmental Psychology, 28, 353-361.

[7] Buhalis, D. (2000). Marketing the competitive destination of the future. Tourism Management, 21, 97-116.

[8] Catell, R. B. (1966). The scree test for number of factors. Multivariate Behavioral Research, 1, 245-276.

[9] Cheng, T. M., Wu, H. C., \& Huang, L. M. (2012). The influence of place attachment on the relationship between destination attractiveness and environmentally responsible behavior for island tourism in Penghu, Taiwan. Journal of Sustainable Tourism, 21(8), 1166-1187.

[10] Chongwa, M.B. (2012). The History and Evolution of National Parks in Kenya: The Kenya Wildlife Service in the 21st Century. The George Wright Forum, 29: 39-42.

[11] Cho, V. (2008). Linking location attractiveness and tourist intention. Tourism and Hospitality Research, $8(3), 220-224$.

[12] Cohen, D. A., \& Golinelli, D. (2009). Effects of Park Improvements on Park Use and Physical Activity: Policy and Programming Implications. American Journal of Preventive Medicine, 37(6), 475-480.

[13] Cohen, D. A., \& Marsh, T. (2010). Parks and physical activity: Why are some parks used more than others? Preventive Medicine, 50(1), 9-12.

[14] Cracolici, M.F. \& Nijkamp, P. (2009). The attractiveness and competitiveness of tourist destinations: A study of Southern Italian regions. Tourism Management, 30, 336-344.

[15] Curtin, S.C., \& Wilkes, K. (2005). British wildlife tourism operators: Current issues and typologies. Current Issues in Tourism, 8(6), 455-478.

[16] Dharani, N., Kinyamario, J. I., \& Onyari, J. M. (2006). Structure and Composition of Acacia xanthophloea woodland in Lake Nakuru National Park, Kenya. African Journal of Ecology, 44, 523-530

[17] Elliot, J., Gibbons, H., King, D., \& King. A., (2014). Exploring Environmental Complimentarity Between Types of Protected Areas in Kenya. Paris: Focales.

[18] Ferrario, F. F. (1979). The evaluation of tourist resources: An applied methodology. Journal of Travel Research, 17(3), 18-22 
[19] Formica, S. (2000). Destination Attractiveness as a Function of Supply and Demand Interaction. $\mathrm{PhD}$ Disertation. Blacksburg, USA.

[20] Formica, S. (2002). Measuring destination attractiveness: A proposed framework, Journal of American Academy of Business, 1(2), 350-355.

[21] Formica, S., \& Uysal, M. (2006). Destination attractiveness based on supply and demand evaluations: An analytic framework. Journal of Travel Research, 44, 418-430.

[22] Gartner, W. (1989). Tourism image: attribute measurement of state tourism products using multidimentional scaling techniques. Journal of Travel Research, 28, 16-20.

[23] Government of Kenya (2010). National Climate Change Response Strategy. Nairobi: Government Printers.

[24] Government of Kenya (2013). National Climate Change Action Plan 2013-2017. Nairobi: Government Printers.

[25] Goeldner, C. R., Ritchie B. J., \& McIntosh, R. W. (2000). Tourism: Principles, practices, philosophies. New York: John Wiley \& Sons.

[26] Gunn, C.A. (1979). Vacationscape: Designing Tourist Regions. New York: Van Nostrand Reinhold.

[27] Gunn, C.A. (1988). Vacationscape: Designing Tourist Regions $\left(2^{\text {nd }} e d\right)$. New York: Van Nostrand Reinhold.

[28] Hair, J., Black, C., Babin, J., Anderson, E., \& Tatham, L. (2006). Multivariate Data Analysis, (6 ${ }^{\text {th }}$ Ed). Ontario: Pearson International.

[29] Harrison-Walker L. J. (2011). Strategic positioning of nations as brands. Journal of International Business Research, 10(2), 135-147.

[30] Henkel, R., Henkel, P., Agrusa, W., Agrusa, J., \& Tanner, J. (2006). Thailand as a tourist destination: Perceptions of international visitors and Thai residents. Asia Pacific Journal of Tourism Research, 11(3), 269-287.

[31] Hou, J. S., Lin, C. H., \& Morais, D. B. (2005). Antecedents of attachment to a cultural tourism destination: The case of Hakka and Non-Hakka Taiwanese visitors to Pei-Pu, Taiwan. Journal of Travel Research, 44(2), 221-233.

[32] Hu, Y. \& Ritchie, J.R. B. (1993). Measuring destination attractiveness: A contextual approach. Journal of Travel Research, 32(2), 25-34.

[33] Kaiser, H. (1970). A second generation Little Jiffy. Psychometrika, 35, 401-415.

[34] Kaiser, H. (1974). An index of factorial simplicity. Psychometrika, 39, 31-36.

[35] Kim, H. B. (1998). Perceived attractiveness of Korean destinations. Annals of Tourism Research, 25, 340 361.

[36] Kim, S. S., \& Lee, C. K. (2002). Push and pull relationships. Annals of Tourism Research, 29(1), 257-260.

[37] Kim, S.S. \& Agrusa, J. (2005). The positioning of overseas honeymoon destinations. Annals of Tourism Research, 887-904.

[38] Kim D., \& Perdue R. R. (2011). The influence of image on destination attractiveness. Journal of Travel \& Tourism Marketing, 28, 225-239.

[39] Kotler, P., Haider, D. H., \& Rein, I. (1993). Marketing Places. New York: Free Press.

[40] Kozak, M., \& Rimmington, M. (1998). Benchmarking: Destination attractiveness and small hospitality business performance. International Journal of Contemporary Hospitality Management, 10, 184-188.

[41] Krešić D., \& Darko Prebežac, D. (2011). Index of destination attractiveness as a tool for destination attractiveness assessment. Original Scientific Papep, 59(4), 497-517.

[42] Krešić, D. (2007). Faktori atraktivnosti turističkih destinacija u funkciji konkurentnosti. Acta Turistica,19(1), 45-82

[43] Laws, E. (1995). Tourism destination management: Issues, analysis, and policies. New York: Routledge.

[44] Leask, A. (2010). Progress in visitor attraction research: Towards more effective management. Tourism Management, 155-166.

[45] Lee, K. (2001). Sustainable tourism destinations: The importance of cleaner production. Journal of Cleaner Production, 9, 313-323.

[46] Lee, C., Chen, P., \& Huang, H. (2014). Attributes of Destination Attractiveness in Taiwanese Bicycle Tourism: The Perspective of Active Experienced Bicycle Tourists. International journal of hospitality \& tourism administration, 15(3), 275-29 
[47] Lee, C. F., Huang, H. I., \& Yeh, H. R. (2010). Developing an evaluation model for destination attractiveness: Sustainable forest recreation tourism in Taiwan. Journal of Sustainable Tourism, 18(6), $811-828$

[48] Lee, C., Ou, W., \& Huang, H. (2009). A study of destination attractiveness through domestic visitors' perspectives: The case of Taiwan's Hot Springs Tourism Sector. Asia Pacific Journal of Tourism Research, 14(1), 17-38.

[49] Leiper, N. (1990). Tourist attraction systems. Annals of Tourism Research, 17, 367-384.

[50] Lew, A. A. (1987). A Framework of tourist attraction research. Annals of Tourism Research, 14(4), 553575.

[51] Lin, C.H., Morais, B., Kerstetter, D.L., \& Hou, J.S. (2007). Examining the role of cognitive and affective image in predicting choice across natural, developed, and theme-park destinations. Journal of Travel Research, 46(4), 183-194.

[52] Lue, C., Crompton, J. L., \& Stewart, W. P. (1996). Evidence of Cumulative Attraction in Multidestination Recreational Trip Decision. Journal of Travel Research, 35(1), 41-50.

[53] Mayaka, M.A. \& Prasad, H. (2012). Tourism in Kenya: An analysis of strategic issues and challenges. Tourism Management 1(1), 48-56.

[54] Mayo, E., \& Jarvis, L. (1981). Psychology of leisure travel. Boston: CABI Publishing

[55] Mburugu, M. M., \& Rotich, G. (2015). Factors influencing the decline of international tourists' arrivals in Kenya. The strategic journal of business \& change management, 2(127), 2137-2182.

[56] McCormack, G. R., \& Rock, M. (2010). Characteristics of urban parks associated with park use and physical activity: A review of qualitative research. Health \& Place, 16(4), 712-726.

[57] Mihalič, T. (2000). Environmental management of a tourist destination: A factor of tourism competitiveness. Tourism Management, 21(1), 65-78.

[58] Morachat, C. (2003). A study of destination attractiveness through tourists' perspectives: A focus on ChiangMai, Thailand. PhD Dissertation, Edin Cowan University, Australia

[59] Munyiri, E. K. (2015). Vulnerability and adaptation of the tourism sector to climate change in Nairobi, coast and central tourist circuits in Kenya. Unpublished Dphil Thesis, Kenyatta University, Kenya.

[60] Murphy, P., Pritchard, M. P., \& Smith, B. (2000). The destination product and its impact on traveler perceptions. Tourism Management, 21(1), 43-52.

[61] Newsome, D., Dowling, R., \& Moore S. (2005). Wildlife Tourism. Aspects of Tourism Series. Clevedon, UK: Channel View Publications.

[62] Nyberg, L. (1994). Determinants of the attractiveness of a tourism region. In S. F. Witt \& L. Moutihno (eds), Tourism marketing and management handbook ( $2^{\text {nd }}$ ed., 24-28). New York: Prentice Hall.

[63] Odunga, P., \& Maingi, S. (2011). The Wildlife Tourism Market to Kenya (2002-2003). Journal of Travel and Tourism Marketing, 28(1), 62-80.

[64] Omerzel, G. D., \& Mihalič, T. (2008). Destination competitiveness-Applying different models, the case of Slovenia. Tourism Management, 294-307.

[65] Pikkemaat, B. (2004). The measurement of destination image: The Case of Austria. The Poznan University of Economics Review, 87-102.

[66] Pyo, S., Uysal, M., \&. McLellan, R. (1991). A Linear Expenditure Model for Tourism Demand. Annals of Tourism Research, 18(3), 443-54.

[67] Ritchie, B. J., \& Crouch, G.I. (2005). The Competitive Destination: A Sustainable Tourism Perspective. Wallingford: CABI Publishing.

[68] Ritchie, B. J. R., \& Zins, M. (1978). Culture as a Determinant of the Attractiveness of a Tourist Region. Annals of Tourism Research, 5 (2), 252-67

[69] Sparks, B. (2007). Planning a wine tourism vacation? Factors that help to predict tourist behavioral intentions. Tourism Management, 28, 1180-1192.

[70] Tam, B. T. (2012). Application of contextual approach for measuring tourism destination attractiveness. Journal of Science, 70(1), 217-226.

[71] Tardivo, G., \& Viassone, M. (2009). How attractive are Italian regions for foreign investment? Methodological approach. Journal of Financial Management and Analysis, 22(1), 48-60.

[72] Tasci, A. D. A., Cavusgil S. T., \& Gartner, W. C. (2007). Conceptualization and Operationalization of Destination Image. Journal of Hospitality \& Tourism Research. 31, 194.

[73] Thiumsak, T., \& Ruangkanjanases, A. (2016). Factors Influencing International Visitors to Revisit Bangkok, Thailand. Journal of economics, business and management, 4(3), 220-230. 
[74] Um, S., Chon, K., \& Ro, Y-H. (2006). Antecedents of revisit intention. Annals of Tourism Research, 33, 1141-1158.

[75] UNWTO. (2003). Tourism proves as a resilient and stable economic sector. URL: http://www.worldtourism.org/newsroom/Releases/more_releases/june2002/ data.htm (Accessed on 24.09.2016).

[76] Van Raaij, W. F. (1986). Consumer research on tourism: Mental and behavioral constructs. Annals of Tourism Research, 13, 1-9.

[77] Vengesayi, S. (2003). A conceptual model of tourism destination competitiveness and attractiveness, ANZMAC Conference Proceedings, 637-647, Adelaide, University of South Australia, 1-3 December.

[78] Vengesayi, S., Mavondo, F. T., \& Reisinger, Y. (2009). Tourism destination attractiveness: attractions, facilities, and people as predictors. Tourism Analysis, 14, 621-636.

[79] World Travel \&Tourism Council (2012). Travel and tourism economic impact, Kenya. London: World Travel and Tourism council.

[80] Yahaya, A., \& Mohd, A. (2013). Products Attributes as Attraction and as Pull Factor towards Sustaining Visitation to Putrajaya Botanical Garden. Journal of social science and Humanity, 21(3), 979-994.

[81] Yoon U., \& Uysal, M. (2005). An Examination of the Effects of Motivation and Satisfaction on Destination Loyalty. Tourism Management, 26(1), 45-46.

[82] Zhou, L. (2005). Destination attributes that attract international tourist to Cape Town. Faculty of Economic and Management Sciences, University of the Western Cape, p22-61.

Citation: George, Ariya et al. "Tourism Destination Attractiveness as Perceived by Tourists Visiting Lake Nakuru National Park, Kenya." International Journal of Research in Tourism and Hospitality (IJRTH), vol 3, no. 4, 2017, pp. 1-13. doi:http://dx.doi.org/10.20431/2455-0043.0304001.

Copyright: (C) 2017 Authors. This is an open-access article distributed under the terms of the Creative Commons Attribution License, which permits unrestricted use, distribution, and reproduction in any medium, provided the original author and source are credited. 